Article

\title{
Bio-Compost-Based Integrated Soil Fertility Management Improves Post-Harvest Soil Structural and Elemental Quality in a Two-Year Conservation Agriculture Practice
}

\author{
Mohammad Mofizur Rahman Jahangir 1,*(D), Shanta Islam ${ }^{1}$, Tazbeen Tabara Nitu ${ }^{1}$, Shihab Uddin ${ }^{1}$ (D), \\ Abul Kalam Mohammad Ahsan Kabir ${ }^{2}$, Mohammad Bahadur Meah ${ }^{3}$ and Rafiq Islam ${ }^{4}$ (D) \\ 1 Department of Soil Science, Bangladesh Agricultural University, Mymensingh 2202, Bangladesh; \\ shantaislam0821@gmail.com (S.I.); tazbeen127@gmail.com (T.T.N.); shihab43151@bau.edu.bd (S.U.) \\ 2 Department of Animal Science, Bangladesh Agricultural University, Mymensingh 2202, Bangladesh; \\ ahsankabiras@bau.edu.bd \\ 3 Department of Plant Pathology, Bangladesh Agricultural University, Mymensingh 2202, Bangladesh; \\ bmeah.ppath@bau.edu.bd \\ 4 Soil, Water and Bioenergy Resources, The Ohio State University South Centers, Piketon, OH 45661, USA; \\ islam.27@osu.edu \\ * Correspondence: mmrjahangir@bau.edu.bd
}

Citation: Jahangir, M.M.R.; Islam, S.; Nitu, T.T.; Uddin, S.; Kabir, A.K.M.A.; Meah, M.B.; Islam, R.

Bio-Compost-Based Integrated Soil Fertility Management Improves

Post-Harvest Soil Structural and Elemental Quality in a Two-Year Conservation Agriculture Practice. Agronomy 2021, 11, 2101. https:// doi.org/10.3390/agronomy11112101

Academic Editor:

Ambrogio Costanzo

Received: 14 September 2021

Accepted: 7 October 2021

Published: 20 October 2021

Publisher's Note: MDPI stays neutral with regard to jurisdictional claims in published maps and institutional affiliations.

Copyright: (c) 2021 by the authors. Licensee MDPI, Basel, Switzerland. This article is an open access article distributed under the terms and conditions of the Creative Commons Attribution (CC BY) license (https:/ / creativecommons.org/licenses/by/ $4.0 /)$.

\begin{abstract}
The impacts of integrated soil fertility management (ISFM) in conservation agriculture need short-term evaluation before continuation of its long-term practice. A split-split plot experiment with tillage (minimum tillage, MT vs. conventional tillage, CT) as the main plot, residue ( $20 \%$ residue, $\mathrm{R}$ vs. no residue as a control, NR) as the sub-plot, and compost (Trichocompost, LC; bio-slurry, BS; and recommended fertilization, RD) as the sub-sub plot treatment was conducted for two consecutive years. Composite soils were collected after harvesting the sixth crop of an annual mustard-ricerice rotation to analyze for nutrient distribution and soil structural stability. The LC increased rice equivalent yield by $2 \%$ over RD and $4 \%$ over BS, and nitrogen (N) uptake by $11 \%$ over RD and $10 \%$ over BS. Likewise, LC had higher soil organic carbon (SOC), N, and available sulphur (S) than BS and RD. Conversion of CT to MT reduced rice equivalent yield by $11 \%, \mathrm{~N}$ uptake by $26 \%$, and $\mathrm{N}$-use efficiency by $28 \%$. Conversely, soil structural stability and elemental quality was greater in MT than in CT, indicating the potential of MT to sequester C, N, P, and S in soil aggregates. Residue management increased rice yield in the second year by $4 \%$ and corresponding $\mathrm{N}$ uptake by $8 \%$. While MT reduced the yield, our results suggest that ISFM with Trichocompost and residue retention under MT improves soil fertility and physical stability to sustain crop productivity.
\end{abstract}

Keywords: conservation agriculture; integrated soil fertility management; trichocompost; soil quality; crop yield

\section{Introduction}

By 2050, the world's population is expected to increase by 2.4 billion, placing added pressure on agricultural systems for food, fuel, and fiber production, and challenging their potential to achieve food security and environmental sustainability [1]. Cultivable lands all over the world are decreasing due to urbanization, rural settlement, and institutionalization [2]. Healthy soil is fundamental for sustained agricultural productivity and the maintenance of vital ecosystem processes. However, achieving an increase in agricultural production, while at the same time improving soil health, is a key research challenge in response to global climate change effects. Current tillage practices are responsible for the degradation of air-soil-water ecosystems [3,4]. The adverse impact of intensive tillage practices on soil physical quality and organic carbon levels is a major challenge in tropical rice-growing regions [5]. Switching to minimum tillage (MT) with crop residue retention is expected to influence the stoichiometrically linked carbon $(C)$, nitrogen $(N)$, phosphorus 
$(\mathrm{P})$, and sulphur $(\mathrm{S})$ cycling processes in soil organic matter and decrease reactive $\mathrm{N}$ and $\mathrm{P}$ losses to the environment, thus increasing use efficiency [6,7]. However, long-term tillage effects on soil quality are still contradictory and depend on soil, climate, and management practices [8]. Therefore, assessment of short-term tillage effects, along with other soil-crop management, is required to give insights into the long-term continuation of the practice. Past research argued that identifying sensitive and consistent indicators of soil quality will allow early management decisions and quick remedial action [7,9].

Sustainable agriculture must find ways to minimize this nutrient inefficiency while maintaining, or even increasing, crop productivity and soil quality. Sole or imbalanced use of chemical fertilizers increases the cost of production, enhances nutrient losses to the environment, and causes several air and water quality concerns, as well as degrades soil health [10]. Soil conservation should be considered an important approach for managing the risks of climate change through adaptation $[11,12]$. Thus, there is an urgent need to preserve the soil resource, which is not renewable at the human time scale, and to aim for its sustainable management. Agricultural soil's C stock can be managed through appropriate choices of sustainable agricultural practices [12,13], such as the use of organic amendments, management of crop residues, and the use of soil amendments with organic fertilizers rather than the sole application of chemical fertilizers [14,15]. Integrated soil fertility management (ISFM) is one of the critical components to maintain and improve agroecosystem services in conservation agriculture. The ISFM has attracted the interest of scientists worldwide with its benefits for increased crop yield and sustainable soil health [16]. Recently, Trichocompost, produced from Trichoderma sp., has been reported to improve crop yield by increasing availability of plant nutrients and water to plants through their enlarged hyphae and by preventing pest infestation $[17,18]$. Understanding how a proactive choice of organic amendment, as in the case of ISFM in MT systems, can help reduce the requirements for $\mathrm{N}$ application. Waste management has become an ever greater burden on the world. Waste conversion to valuable composts has become a potent technology for sustainable waste management [19]. However, bio-composts preparation using municipal and animal farm wastes for use in agriculture is more viable, although these may contain some trace element that can pollute soils [20]. Nonetheless, animal farm wastes are richer in $\mathrm{N}$ and other nutrients, homogenous, and easier to sort for biocompost preparation, but their conversion to bio-compost and evaluation for trace element contents and application in agriculture has not been reported. We hypothesize that organic amendments in MT will enhance soil organic matter accumulation, which in turn will increase the storage of essential plant nutrients in soils. The specific objectives of the current research are to: (i) assess the quality of Trichocompost with regard to chemical composition and heavy metal contaminations, and (ii) investigate the effect of tillage, residue management, and Trichocompost-based ISFM on crop yield, $\mathrm{N}$ uptake and N-use efficiency, soil aggregate stability, and nutrient distribution.

\section{Materials and Methods}

\subsection{Site Description}

The experiment was conducted at the Soil Science Field Laboratory at the Bangladesh Agricultural University, Mymensingh ( $24^{\circ} 54^{\prime \prime}$ N Latitude, $90^{\circ} 50^{\prime \prime}$ E Longitude, Altitude $18 \mathrm{~m}$ above ordnance datum). The mean temperature of the site is $25^{\circ} \mathrm{C}$. The soil was Brahmaputra alluvium with soil organic C $1.62 \%$ and total nitrogen (TN) $0.11 \%$ with low soil-available $\mathrm{P}, \mathrm{S}$, and $\mathrm{K}$ and medium $\mathrm{Zn}$ content (Table 1). Soil texture is a silt loam in topsoil with a bulk density of $1.32 \mathrm{~g} \mathrm{~cm}^{-3}$. The mean annual rainfall is $2200 \mathrm{~mm}$ and humidity is $79.85 \%$. The site has been used in conventional tillage (CT) systems with an intensively managed rice-based ecosystem for around 100 years, resulting in soil nutrient mining and poor elemental quality. 
Table 1. Initial soil properties before commencement of the experiment; $n=3$.

\begin{tabular}{|c|c|c|c|c|c|c|c|c|c|c|}
\hline $\mathrm{pH}$ & $\begin{array}{l}\text { Soil } \\
\text { Organic } \\
\text { Carbon } \\
\text { (SOC) }\end{array}$ & $\begin{array}{l}\text { Total } \\
\text { Nitro- } \\
\text { gen } \\
\text { (TN) }\end{array}$ & $\begin{array}{l}\text { Available } \\
\text { Phospho- } \\
\text { rus } \\
\text { (P) }\end{array}$ & $\begin{array}{l}\text { Exchangeable } \\
\text { Potassium } \\
\text { (K) }\end{array}$ & $\begin{array}{l}\text { Available } \\
\text { Sulphur } \\
\text { (S) }\end{array}$ & $\begin{array}{l}\text { Available } \\
\text { Zinc } \\
\text { (Zn) }\end{array}$ & $\begin{array}{l}\text { Cadmium } \\
\text { (Cd) }\end{array}$ & $\begin{array}{c}\text { Nickel } \\
\text { (Ni) }\end{array}$ & $\begin{array}{l}\text { Lead } \\
(\mathrm{Pb})\end{array}$ & $\begin{array}{c}\text { Copper } \\
\text { (Cu) }\end{array}$ \\
\hline & \multicolumn{2}{|c|}{$(\%)$} & \multicolumn{8}{|c|}{ (ppm) } \\
\hline 6.45 & 1.62 & 0.11 & 10.44 & 31.2 & 2.56 & 1.10 & 0.01 & 0.05 & 0.50 & 4.2 \\
\hline
\end{tabular}

\subsection{Preparation of Trichocompost}

Horse, sheep, and goat dung were collected from the BAU animal farm, then sorted, ground properly, and mixed at a ratio of 1:1:1 (horse:sheep:goat). Compost preparation pits (length $\times$ width $\times$ depth $=92 \mathrm{~cm} \times 50 \mathrm{~cm} \times 88 \mathrm{~cm}$ ) were previously prepared with concrete. Trichoderma harzianum CP (IPM-22) was collected and cultured in acidified potato dextrose agar (APDA) medium. It was then sub-cultured on the same medium for multiplication through incubation at room temperature $\left(25 \pm 1^{\circ} \mathrm{C}\right)$. Then Trichoderma suspension $(200 \mathrm{~mL}$; spore density $4.5 \times 10^{8} \mathrm{CFU}$ ) was prepared from a 7-day old culture. Firstly, two-thirds of the area of each pit was filled by composting materials before Trichoderma suspension was applied. Finally, the pits were filled completely with the composting material and mixed thoroughly with Trichoderma suspension. The composting materials in the compost pits were mixed well at 7-day intervals and sampled for physical and chemical quality analysis until the composts became mature in 45 days. The colony of Trichoderma harzianum was visible like spider nets throughout the compost preparation period.

\subsection{Experimental Design}

A split-split plot experiment was established with two sets of tillage treatments viz. MT vs. CT; two sets of residue retention treatments $(20 \%$ of residue by plant height, $\mathrm{R}$ and no residue, control, NR); and three sets of bio-compost treatments (Trichocompost + rest of the nutrients from fertilizers, bio-slurry + rest of the nutrients from chemical fertilizers). The entire field was replicated into three blocks, with each block being divided into two main plots of tillage. Each main plot was divided into sub-plots of residue retention, and each sub-plot was divided into three sub-plots of bio-composts. Each replicated plot was $10 \mathrm{~m}$ long $\times 5 \mathrm{~m}$ wide. The cropping pattern was mustard-rice-rice in an annual sequence spanning a period of 12 months. In the MT system, light ploughing at $5 \mathrm{~cm}$ depth was performed by one pass of a power tiller. By contrast, in the CT system, $15 \mathrm{~cm}$ deep ploughing was performed by four passes of a power tiller. The design of the experiment is provided in Supplementary Materials 1.

\subsection{Crop Management and Plant and Soil Sampling}

The recommended high yielding varieties of mustard (cv. BARI Shorisa14; Brassica napus), transplanted Boro rice (cv. BRRI dhan28; Oryza sativa L.) and transplanted Aman rice (cv. BRRI dhan71; Oryza sativa L.) were used as test crops. The recommended dose (RD) of N, P, K, S, and B were 90, 27, 40, 10, and $1 \mathrm{~kg} \mathrm{ha}^{-1}$ for mustard; 120, 25, 60, 11, and $6 \mathrm{~kg} \mathrm{ha}^{-1}$ for transplanted Boro rice; and 80,18, 28,6, and $1 \mathrm{~kg} \mathrm{ha}^{-1}$ for transplanted Aman rice (Fertilizer Recommendation Guide, 2012), respectively. The N, P, K, S, Zn, and B were applied as urea, triple superphosphate (TSP), muriate of potash (MoP), gypsum, zinc sulphate $\left(\mathrm{ZnSO}_{4} .7 \mathrm{H}_{2} \mathrm{O}\right)$, and boric acid, respectively. In Trichocompost (TC) and bio-slurry (BS)-based ISFM treatments, $25 \%$ of the nutrients was applied from the compost or bio-slurry and rest of the amounts were compensated from chemical fertilizer to fulfil the RD. Trichocompost and bio-slurry were applied at the rate of 5.85 and $9.107 \mathrm{~kg} \mathrm{plot}^{-1}$ for mustard, 7 and $10 \mathrm{~kg} \mathrm{plot}^{-1}$ for boro rice, and 4.5 and $7 \mathrm{~kg} \mathrm{plot}^{-1}$ for T. Aman rice, respectively. While the total amount of TSP, MoP, gypsum, $\mathrm{ZnSO}_{4}$, and boric acid was applied during final land preparation, the urea was applied in three equal splits for rice, and two equal splits for mustard. For rice, urea was applied at 10, 30, and 50 days after 
transplanting, and for wheat it was applied at 15 and 35 days after sowing following light irrigation. Split application of urea is conventionally practiced for minimizing the loss of $\mathrm{N}$ by volatilization and denitrification, and to make it available to crops at their critical stage, which enhances $\mathrm{N}$-use efficiency. All nutrients were compensated considering the nutrient content in crop residues and organics following the integrated plant nutrition system approach. Each crop was harvested at full maturity at a height leaving $20 \%$ residues and grain yield was estimated. At harvest, crop yield data were collected from a randomly selected geo-referenced micro plot $\left(4 \mathrm{~m}^{2}\right)$ in the middle of each replicated plot for all crops. For those plots that received residues, crops were cut leaving 20\% (height basis) residues, while those plots that received no residues were cut at the ground level. Yield of the residues left in the plot were estimated separately and pooled together with the straw yield. To evaluate the tillage, residue, and ISFM impact on temporal crop yields (deductive soil quality), the rice equivalent yield (REY) was calculated. The straw yield of rice and grain yield of mustard were converted to REY, based on the unit market price of straw and mustard following Equation (1) below [21]:

$$
\text { Rice Equivalent Yield }\left(t h a^{-1}\right)=\frac{\text { mustard yield }\left(t h a^{-1}\right) \times \text { unit price of mustard }}{\text { unit price of rice }}
$$

Composite soil samples were collected at $0-15 \mathrm{~cm}$ depth from each replicated plot after harvesting the sixth crop in November 2018. After air drying at $25^{\circ} \mathrm{C}$ for around two weeks, one portion of the soil samples was used for soil aggregate properties and another portion was used for soil chemical analysis. The representative grain and straw samples were collected from $4 \mathrm{~m}^{2}$ micro plots (five hills from each plot). Straw and grains from these hills were separated, weighed, and dried in an oven at $65^{\circ} \mathrm{C}$ for about 48 hours before they were ground by a Ball Mill grinder (PM400, Germany). While calculating the yield, moisture content of the grains was adjusted at $14 \%$. The ground samples were stored in paper bags in a desiccator until analysis. Rice grain and straw were analysed for estimating TN content and $\mathrm{N}$ uptake per ha.

\subsection{Measurement of Soil Aggregate Properties}

For soil water stable aggregate analysis, air-dried soil was broken down into aggregates, $5 \mathrm{~mm}$ sieved, and analysed for aggregate size distribution. Soil aggregate size distribution was performed by using the wet sieving method to obtain water-stable aggregates [22] using $250 \mathrm{~g}$ soil over a sequence of sieves using mesh sizes 2.0, 0.85, 0.30, 0.15, and $0.053 \mathrm{~mm}$. Soil aggregate fraction retained on each sieve, after being dispersed in water on a planetary shaker at a rate of $31 \mathrm{rpm}$, was transferred in a nickel cup and oven-dried at $65^{\circ} \mathrm{C}$ until a constant weight was obtained. Respective mass of each aggregate size of soil was converted to the relative percentage (over the total mass of aggregates). Aggregate mean weight diameter (MWD) was determined using the below equation [23,24].

$$
M W D=\frac{\sum_{i=1}^{i=n} m i \cdot d i}{\sum_{i=1}^{i=n} m i}
$$

where $m i$ and $d i$ are weight and the mean diameter of aggregate fraction $i$, respectively.

\subsection{Analysis of Soil Chemical Properties}

Soil samples used for the elemental analysis were ground in a ball mill grinder (PM400, Germany) and sieved through a $2 \mathrm{~mm}$ sieve. The SOC was determined using the chromicsulfuric acid oxidation method [25], and TN determined using the semi-micro Kjeldahl method [26]. Soil-available P was determined by the Olsen method [27]. Available S was measured by colorimetric method [28]. The TN in grain and straw was determined by semimicro Kjeldahl method [26]. In brief, $0.1 \mathrm{~g}$ of oven-dried ground sample (grain and straw 
separately) was taken in a digestion flask and $1.1 \mathrm{~g}$ catalyst mixture $\left(\mathrm{K}_{2} \mathrm{SO}_{4}: \mathrm{CuSO}_{4} \cdot 5 \mathrm{H}_{2} \mathrm{O}: \mathrm{Se}\right.$ $=100: 10: 1$ ) and $3 \mathrm{~mL} \mathrm{30} \% \mathrm{H}_{2} \mathrm{O}_{2}$ and $5 \mathrm{~mL} \mathrm{H}_{2} \mathrm{SO}_{4}$ were added to it. The flask was swirled and allowed to stand for around $10 \mathrm{~min}$. After cooling, the content was taken in a $100 \mathrm{~mL}$ volumetric flask and the volume was filled to the mark with distilled water and titrated with $0.01 \mathrm{~N} \mathrm{H}_{2} \mathrm{SO}_{4}$.

Total concentration of heavy metals: cadmium $(\mathrm{Cd})$, nickel $(\mathrm{Ni})$, copper $(\mathrm{Cu})$, and lead $(\mathrm{Pb})$ in the final product of the Trichocompost was determined after six weeks of composting using an atomic absorption spectrophotometer (Hitachi ZA3000). Bio-slurry compost was collected from a biogas plant as a solid residue left after biogas production. Compost maturity was tested using standard laboratory methods e.g., C mineralization pattern and germination index. It appeared that the composts became mature after six weeks of composting.

\subsection{Calculation of Plant Nutrient Uptake and Use Efficiency}

Nitrogen uptake by rice plant was calculated by multiplying the $\mathrm{N}$ concentrations in grain and straw by the total mass of grain and straw per ha [29]. Nitrogen use efficiency (NUE), an indicator for the utilization of $\mathrm{N}$ in agriculture and food systems, was calculated using Equation (3) below given by EUNEP [30].

$$
N U E=\frac{\text { Noutput in harvested products }\left(\mathrm{kg} \mathrm{ha}^{-1}\right)}{N \text { input }\left(\mathrm{kg} \mathrm{ha}^{-1}\right)} \times 100
$$

\subsection{Statistical Analysis}

A three-way analysis of variance (ANOVA) was performed using tillage, residue, and fertilizers as fixed variables and block as a random variable. The distribution of data for normality was checked before ANOVA. Data were statistically analysed to ascertain the significant differences in the main plot, and interactions among main and subplot treatments at $p<0.05$, unless otherwise mentioned. Pairwise comparisons were undertaken by Tukey's HSD post-hoc test. All the statistical analyses were performed on SPSS Version 20 (IBM SPSS Statistics for Windows, Version 20.0. Armonk, NY, USA: IBM Corp.).

\section{Results}

\subsection{Quality of the Prepared Trichocompost}

The growth and development of Trichoderma harzianum in the compost were ensured as the colony of the fungi was visible throughout the composting period and in the prepared compost. Organic carbon contents in the Trichocompost were comparatively higher (approximately $28.11 \%$ ) while that of the TN was low (1.50\%), exhibiting a C:N of 18.8:1.0 (Table 2). The available $P$ and $S$ of the prepared compost were 158.4 and $80.2 \mathrm{mg} \mathrm{kg} \mathrm{soil}^{-1}$ and exchangeable $\mathrm{K}$ was $45 \mathrm{meq} .100 \mathrm{~g} \mathrm{soil}^{-1}$. The $\mathrm{pH}$ of the compost was alkaline (>7.0). Before composting, the concentrations of heavy metals were in the order of zinc $(\mathrm{Zn})>$ lead $(\mathrm{Pb})>\operatorname{nickel}(\mathrm{Ni})>\operatorname{copper}(\mathrm{Cu})>\operatorname{cadmium}(\mathrm{Cd})$ (Figure 1$)$. After seven weeks of composting, $\mathrm{Zn}$ and $\mathrm{Pb}$ concentrations increased by 35 and $4 \%$, respectively, over the initial concentrations while the $\mathrm{Cd}, \mathrm{Ni}$ and $\mathrm{Cu}$ concentrations decreased by $10 \%, 88 \%$, and $38 \%$, respectively. The heavy metal contents in soil after two years of cropping with Trichocompost along with their threshold values are presented in Table 3. Heavy metal content in soil before the commencement of the experiment and after two years of cropping with Trichocompost was alike, except a slight increase in Zn. However, all heavy metal contents in soils were much less than the threshold values, indicating no sign of concerns for heavy metal accumulation through Trichocompost. In addition, the soil was deficient in $\mathrm{Zn}$, which requires application of $\mathrm{Zn}$ fertilizer (i.e., $\mathrm{ZnSO}_{4} .7 \mathrm{H}_{2} \mathrm{O}$ or $\mathrm{ZnO}$ ). The increment of Zn will help reduce its deficiency in the soil. 
Table 2. Chemical properties of the prepared Trichocompost and bio-slurry; $n=3$.

\begin{tabular}{ccccccccc}
\hline Organics & $\mathbf{p H}$ & $\begin{array}{c}\text { Moisture } \\
\mathbf{( \% )}\end{array}$ & Avail. P (ppm) & $\begin{array}{c}\text { Avail. S } \\
(\mathbf{p p m})\end{array}$ & $\begin{array}{c}\text { Exch. K } \\
(\mathbf{m e q} . / 100 \text { g) }\end{array}$ & $\begin{array}{c}\text { Organic } \\
\text { Matter (\%) }\end{array}$ & Total N (\%) & $\begin{array}{c}\text { C/N } \\
\text { Ratio }\end{array}$ \\
\hline LC & $7.7 \pm 0.02$ & $14.2 \pm 1.04$ & $158.4 \pm 13.0$ & $80.2 \pm 6.1$ & $45 \pm 8.4$ & $48.9 \pm 0.2$ & $1.5 \pm 0.1$ & $18.8 \pm 2.0$ \\
BS & $6.8 \pm 0.02$ & $30.0 \pm 3.0$ & $60.6 \pm 12.0$ & $28.0 \pm 4.2$ & $30.4 \pm 5.3$ & $18.3 \pm 3.2$ & $1.0 \pm 0.0$ & $11.0 \pm 2.3$ \\
\hline
\end{tabular}

i.e., $\mathrm{LC}=$ Trichocompost, and BS $=$ Bio-slurry.

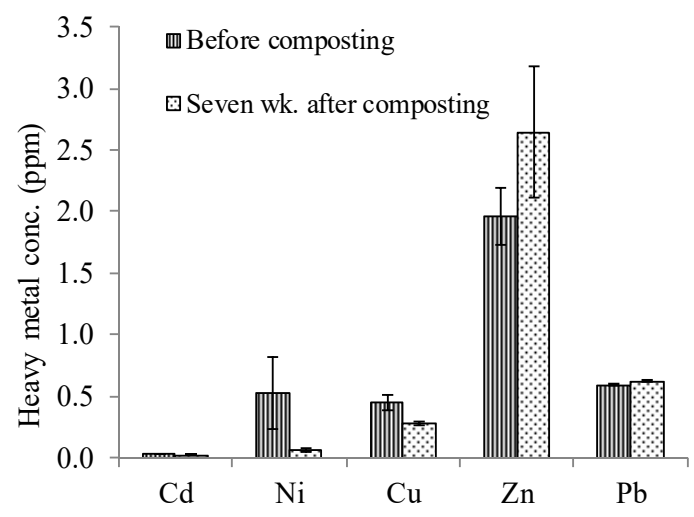

Figure 1. Heavy metal concentrations in Trichocompost.

Table 3. Heavy metal contents in soils after two years of cropping with Trichoderma bio-compost; the threshold values for heavy metal contents in organic amendments in Bangladesh are given in parentheses.

\begin{tabular}{cccccc}
\hline $\mathbf{C r}$ & $\mathbf{C d}$ & $\mathbf{P b}$ & $\mathbf{N i}$ & $\mathbf{Z n}$ & $\mathbf{C u}$ \\
\hline \multicolumn{5}{c}{$(\mathrm{ppm})$} \\
\hline$<\mathrm{MDL}(18.28)$ & $0.01(0.18)$ & $0.50(22.50)$ & $0.05(24.44)$ & $1.51(400)$ & $3.91(160)$ \\
\hline i.e., $\mathrm{MDL}=$ method detection limit. & &
\end{tabular}

\subsection{Management Impacts on System Productivity}

In both 2017 and 2018, the rice equivalent yield (REY) was 11.3 and 11.4\% higher in CT than that in MT $(p<0.01)$ (Figure 2), respectively. Crop residue retention had significantly higher REY in plots under residue than no residue $(p<0.05)$ in 2018 (approximately $4 \%$ higher in R over the NR), but not in 2017 ( $p>0.05)$. Equally, Trichocompost increased the REY only in 2018, being $2 \%$ and $4 \%$ higher than in BS and RD, where the later two were alike. There were no significant interaction effects of tillage, residue, and ISFM treatments.
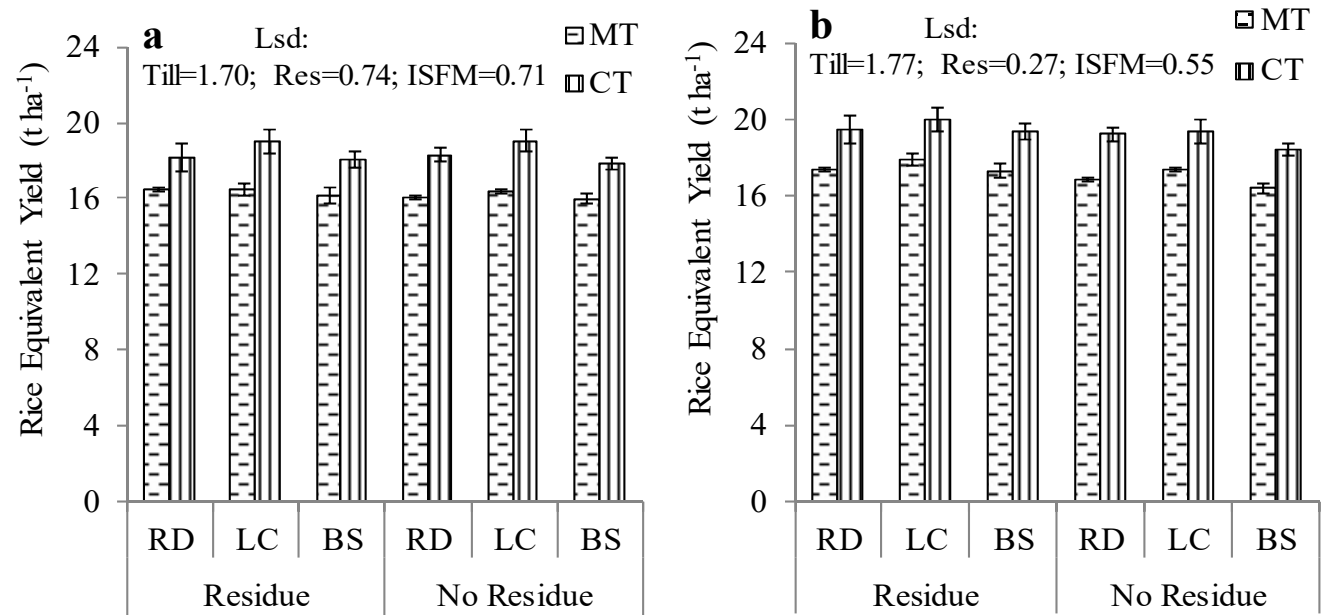

Figure 2. Management impacts on rice equivalent yield (REY) for two consecutive years (a) 2017 and (b) 2018. 


\subsection{Management Impacts on N Uptake and Use Efficiency in Transplanted Aman Rice (6th Crop)}

Grain N content was significantly higher in CT than in MT $(p<0.05)$ (Figure 3), accounting for $14 \%$ higher TN content in CT than in MT. Likewise, the grain N content was significantly higher in the plots under residue than those with no residue (approximately $5 \%$ higher in $\mathrm{R}$ over the NR). The ISFM significantly influenced rice grain $\mathrm{N}$ content $(p<0.01)$ (approximately $1.57 \%, 1.57 \%$, and $1.50 \%$, respectively, in BS, LC, and RD). Grain N content was $5 \%$ higher in $\mathrm{LC}$ and $\mathrm{BS}$ than in RD, where the former two were alike (Figure 3).

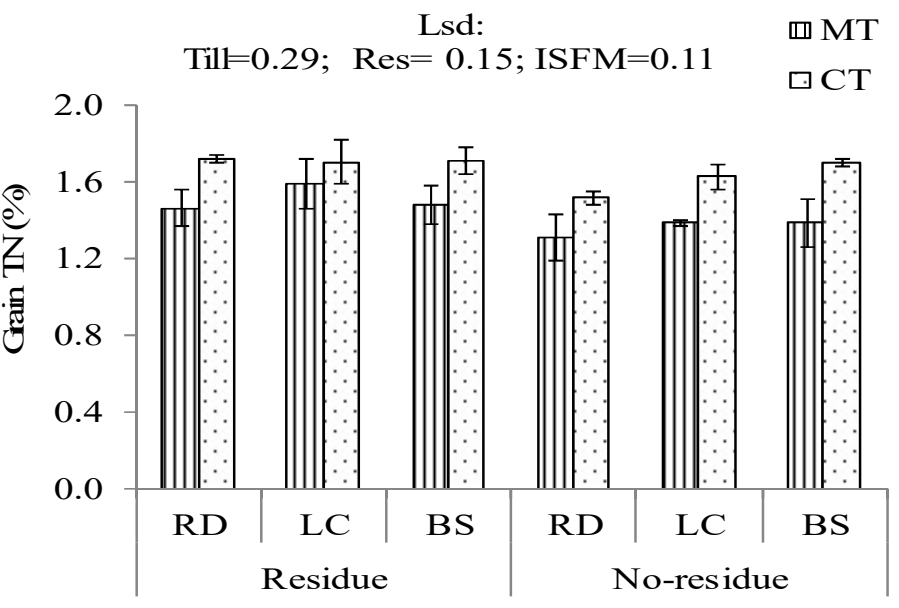

Figure 3. Management effect on grain total nitrogen (TN) content.

There was a significant influence of tillage and ISFM on N uptake and NUE by rice (Figure 4a). Nitrogen uptake by rice paddy was significantly higher in CT than in MT $(p<0.01)$ (approximately 25\% in CT over the MT). Concerning crop residue retention, grain $\mathrm{N}$ uptake was significantly higher $(p<0.05)$ in residue-treated plots than those with no residue (approximately $8 \%$ higher in R than in NR). Similarly, the ISFM did affect rice $\mathrm{N}$ uptake significantly $(p<0.05)$, being higher in LC by 11 and $10 \%$ than in BS and RD, respectively, where the latter two were similar to each other. Nitrogen-use efficiency was higher in CT than in MT $(p<0.01)$ by $36 \%$. In contrast, NUE was similar in R to NR $(p>0.05)$ (Figure $4 \mathrm{~b})$. The LC had significantly higher NUE by $6 \%$ over BS and $7 \%$ over $\mathrm{RD}$, where $\mathrm{BS}$ and $\mathrm{RD}$ were alike. The mean values were $49.5,52.5$, and $49.0 \%$ in $\mathrm{RD}, \mathrm{LC}$, and BS, respectively (Figure 4 b).

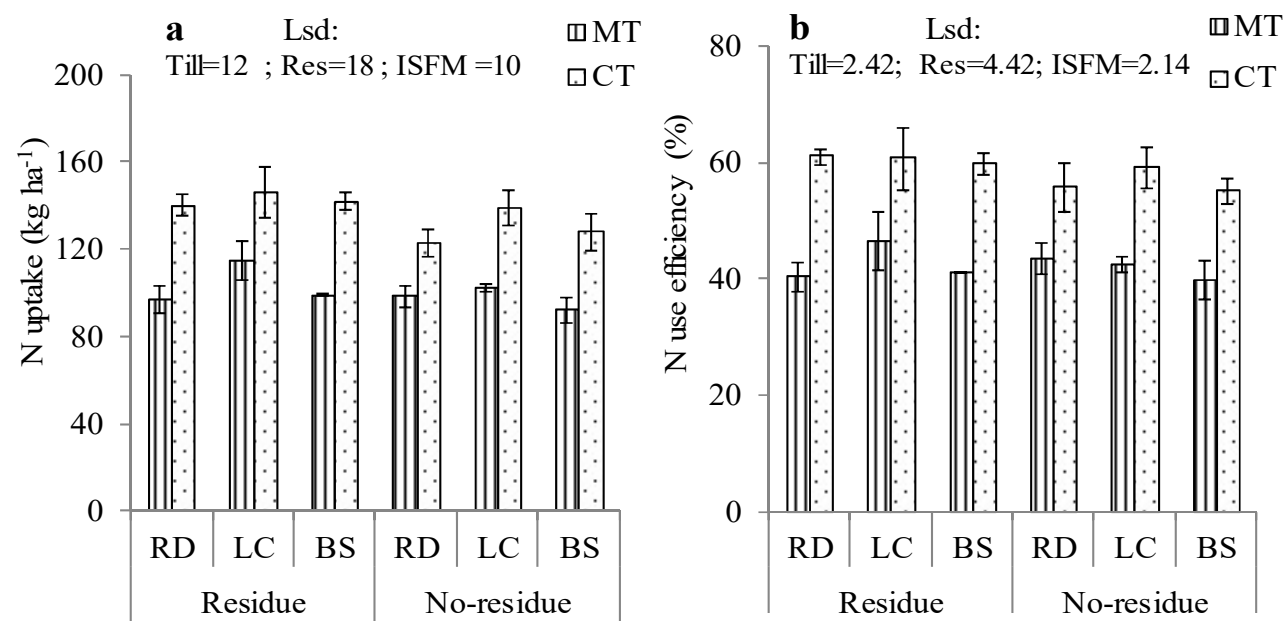

Figure 4. Management impacts on N uptake and N-use efficiency (NUE) for two consecutive years (a) 2017 and (b) 2018 . 


\subsection{Management Impacts on Soil Aggregate Mean Weight Diameter (MWD)}

Soil aggregate MWD was significantly influenced by tillage $(p<0.05)$, ISFM $(p<0.05)$, and crop residue retention $(p<0.05)$. Aggregate MWD was higher in MT by $11 \%$ than in CT (Figure 5). The MWD, irrespective of crop residue retention, was 1.03, 1.10, and $1.14 \mathrm{~mm}$ in MT and $0.95,1.04$, and $1.08 \mathrm{~mm}$ in CT in RD, BS, and LC, respectively. The LC and BS had higher MWD than the RD, where the former two were similar to each other. Considering crop residue retention, MWD was higher in R plots by $19 \%$ than in NR plots. The MWD, irrespective of ISFM, was 0.99 and $1.19 \mathrm{~mm}$ in MT and 0.94 and $1.11 \mathrm{~mm}$ in CT in NR and $\mathrm{R}$, respectively. The interaction effects of tillage, residues, and ISFM were non-significant.

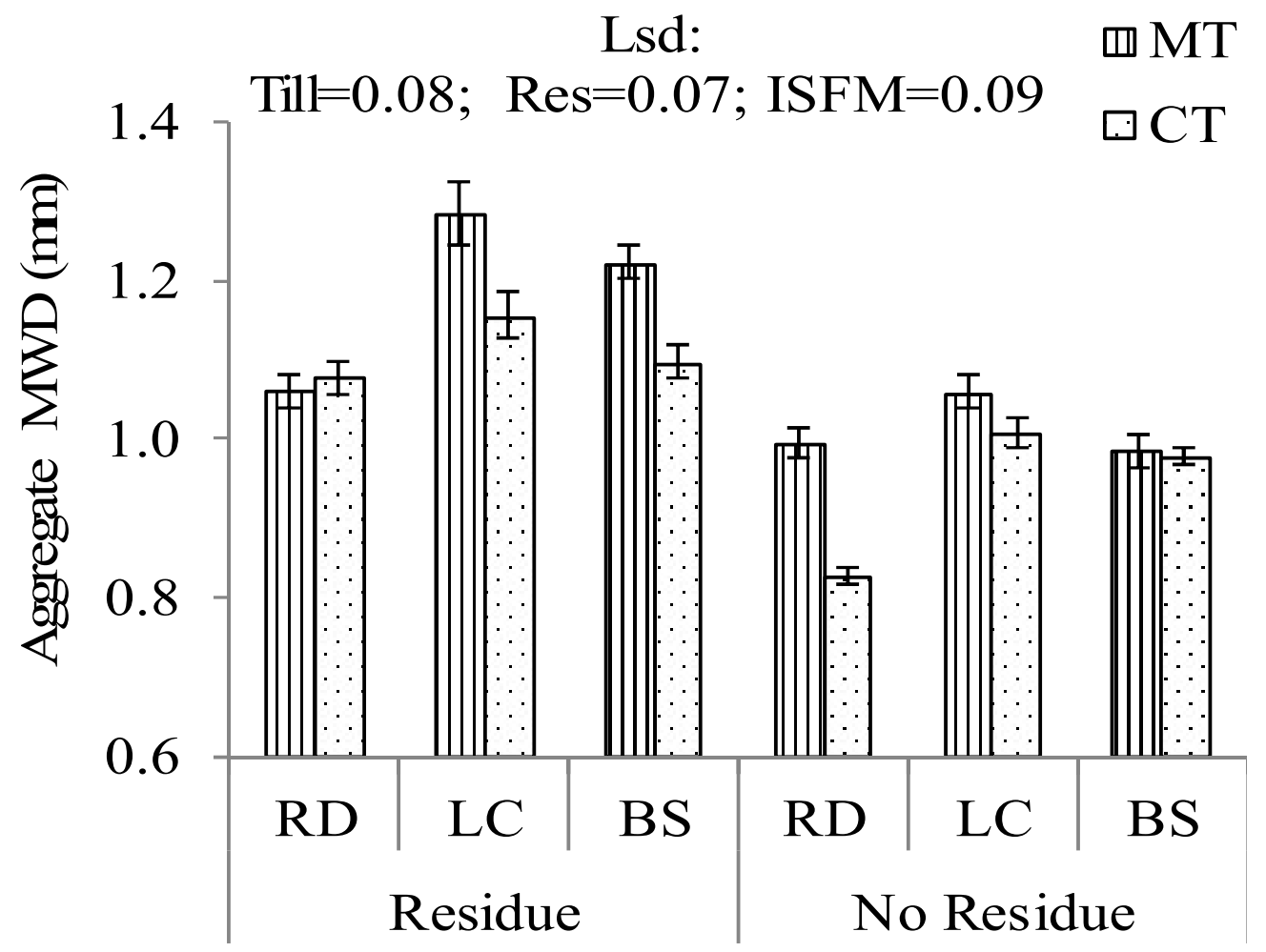

Figure 5. Post-harvest soil aggregate mean weight diameter (MWD) after two consecutive years of integrated soil fertility management (ISFM) with crop residue and tillage practices.

\subsection{Management Impacts on Post-Harvest Soil Organic Carbon (SOC) and Total Nitrogen (TN) Contents}

The SOC content was significantly influenced by tillage $(p<0.01)$ and ISFM $(p<0.05)$, but the effect was non-significant $(p>0.05)$ for crop residue retention. The SOC was significantly higher in MT than in CT by $15 \%(p<0.01)$ (Figure 6a). The ISFM significantly influenced SOC contents $(p<0.05)$, showing the mean values of $1.97 \%, 2.04 \%$, and $1.88 \%$, respectively, in BS, LC, and RD. The LC and BS had higher SOC by $9 \%$ and $5 \%$ than in $\mathrm{RD}$, where the former two were similar to each other. Soil TN content was significantly influenced by ISFM $(p<0.05)$, but no significant influences were observed by tillage and crop residue retention (Figure $6 \mathrm{~b})$. The TN was lower in $\mathrm{RD}(p<0.05)$ by $12 \%$ and $6 \%$ than in LC and BS, respectively, where LC and BS were similar to each other $(p>0.05)$. The interaction effects of tillage, residue, and ISFM were non-significant. 
a Lsd: $\quad$ 四 $\quad$ b $\quad$ Lsd: $\quad \square M T$
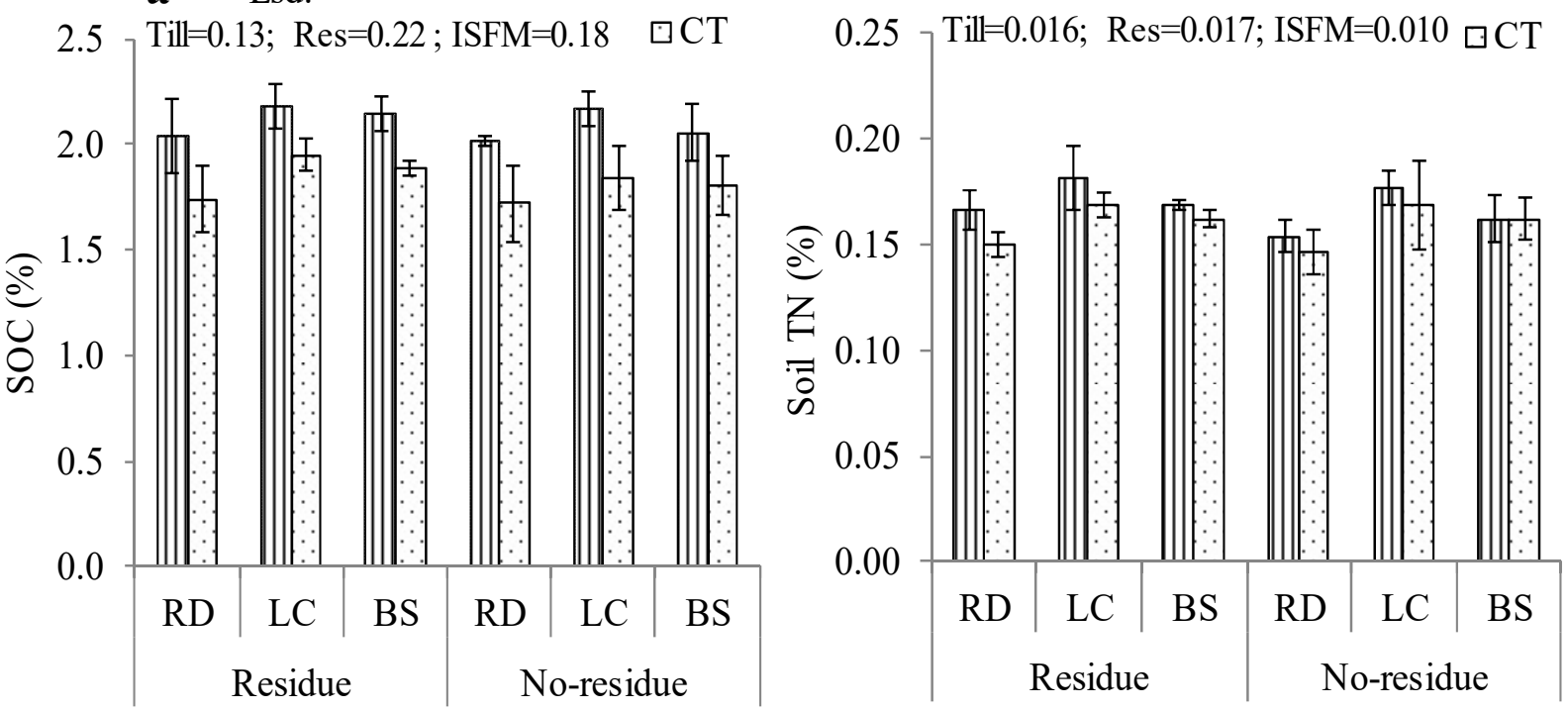

Figure 6. Post-harvest soil organic carbon (SOC) and TN contents after two consecutive years (a) 2017 and (b) 2018 of ISFM with crop residue and tillage practices management impacts on post-harvest soil.

\subsection{Management Impacts on Post-Harvest Soil-Available P and S}

Tillage and residue retention had significant influences on post-harvest soil-available P (Figure 7a), showing 30\% and 26\% higher available P in MT $(p<0.05)$ and R $(p<0.05)$ over the CT and NR, respectively (Figure 7a). The available P was similar in all ISFM treatments $(p>0.05)$. Soil-available S content was significantly higher in MT by $23 \%$ than in CT $(p<0.05)$ (Figure 7b). However, available $S$ in soils with residue $(R)$ was similar to that in NR $(p>0.05)$. Conversely, ISFM significantly influenced soil-available $\mathrm{S}$ content, where the RD had significantly lower available $S$ than BS and LC $(p<0.05)$, where the latter two were also significantly different $(p<0.05)$. Available $S$ was higher in LC and BS by $42 \%$ and $18 \%$, respectively, over the RD, where the BS had higher available $\mathrm{P}$ by $16 \%$ over the RD. No significant interaction effects were observed between tillage, residues, and ISFM.

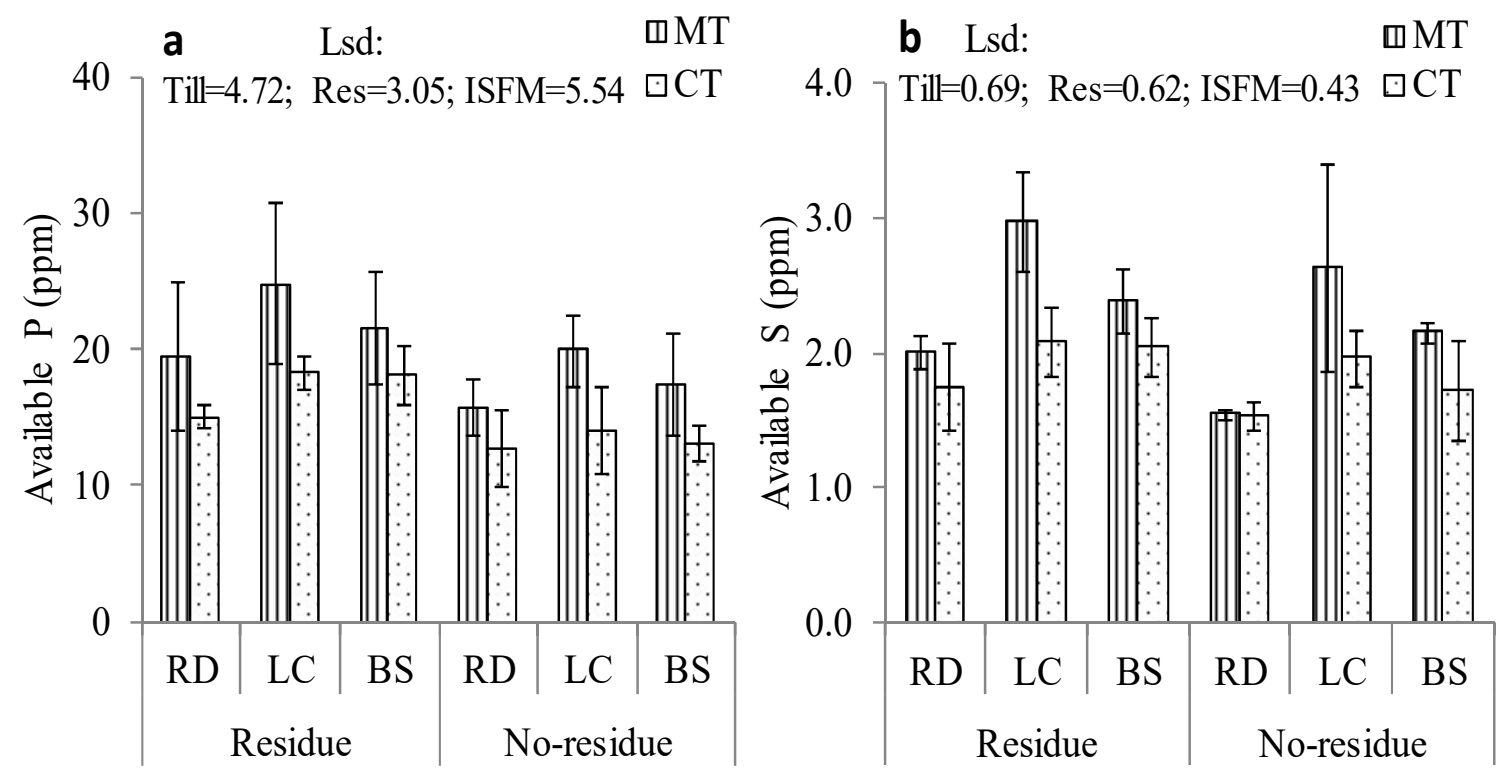

Figure 7. Post-harvest soil available P and S contents after two consecutive years (a) 2017 and (b) 2018 of ISFM with crop residue and tillage practices management impacts on post-harvest soil. 


\section{Discussion}

\subsection{Quality of Trichocompost}

The Trichocompost was of good quality with regard to $\mathrm{pH}$, moisture, $\mathrm{SOM}$, and C:N ratio. It was rich in available $\mathrm{P}$ and $\mathrm{S}$ (Table 2). A C:N ratio $<25$ indicates the state of composting, which helps increase mineral nutrient availability in soils for plant, while the C:N ratio $>25$ indicates the immobilization of mineral nutrients, resulting in unavailability for plants [31]. Heavy metals content in the Trichocompost was lower than in the mixture of the composting materials. On the contrary, Zn content increased in the Trichocompost, which will help increase $\mathrm{Zn}$ uptake by crops, especially in the Zn-deficient soils [32]. The decrease in $\mathrm{Ni}, \mathrm{Cd}$, and $\mathrm{Cu}$ concentration might have been caused by microbial assimilation in Trichoderma and other microbes or fixed with organic fractions. The rise in the $\mathrm{Zn}$ concentration in compost may be attributable to solubilization of the insoluble forms of $\mathrm{Zn}$ in the manures. However, the increase in $\mathrm{Zn}$ concentration will add high value to the compost for amending rice paddy soils that are $\mathrm{Zn}$ deficient. Overall, Trichoderma sp. is a quick decomposer and, upon its inoculation into composting materials, it enhances the composting process [18]. When applied in soil, Matin et al. [18] also found that it increases soil organic matter decomposition, resists pest infestation, and promotes plant growth.

\subsection{Effect of Management Practices on the System Productivity}

Significantly lower REY in the early stage of adoption of MT is not surprising because our results were in agreement with past research [33], where the authors also reported lower crop yield in MT than in CT. Similarly, Alam et al. [34] and Arvidsson and Håkansson [35] found significantly higher yield in deep tillage than in NT (no tillage) or MT. In contrast to our results, Memon et al. [14] found higher grain yield in MT than in CT in the rice-wheat cropping systems of eastern China. This variation in the effects of MT or CT on crop yields can also vary due to soil and climatic variations. However, long-term practices with reduced and CT tillage [36] showed opposite results to our short-term finding, suggesting that MT, over the long term, increases crop yield. Nandan et al. [37] found higher crop yield under reduced or NT systems over the $\mathrm{CT}$ after six years of adoption of conservation tillage. NT or MT can increase rice yield over a continuous application for around four to six years [15]; or six to seven years [38]. These findings were in agreement with Jahangir et al. [39], who stated that adoption of MT gives lower yield in the first few years (3-4) and then the yield turns opposite in later years if it is continued. This might be due to the build-up of organic matter in the MT practice that occurred with the progress of cropping cycles [34].

Our results of crop residue retention on crop yield in a consecutive mustard-rice-rice system, being similar in R to NR in the first year (2017), are opposite to many past research reports. However, in the second year of continuation with the same cropping system, REY was higher in $\mathrm{R}$ than in NR. This can be attributed to the required time lag to build up soil physical and chemical quality for improving the crop yield. Hossain et al. [40] reported residue yielded higher grain yield compared to no residue. Residue converts into mineralized nutrients that cause sufficient crop growth and facilitate higher yield than no residue [41-43]. Increased rice yield by ISFM over the sole application of chemical fertilizer is in agreement with other researches [44,45]. It is assumed that, compared to inorganic fertilizer, organic manure releases nutrients slowly and plants receive a steady supply of nutrients with reduced $\mathrm{N}$ loss, which has a positive reflection on crop yield. However, mineralization of livestock manures was found slower, releasing $25-42 \%$ more $\mathrm{N}$ than the control over 90 days of incubation, resulting in slow $\mathrm{N}$ fertilization effects [46]. The slower mineralization can be attributable to the equal REY in R and NR in the first year in our study. However, slow mineralization can provide residual effects in the following year, which was evident in our study. Roobroeck et al. [16] reported that ISFM can significantly enhance the crop productivity and profitability of farmers. Bilkis et al. [17] reported that integrated application of Trichocompost and cow dung bio-slurry in rice field increases rice yield, where Trichocompost was found to be more effective than the bio-slurry. The better 
performance of LC may be due to higher nutrient contents, including Zn, enlarging soil volume for nutrient and water uptake by fungal hyphae, reducing pest infestation [18], and functioning as a plant growth promoter [47]. In a rice paddy system, soils are commonly identified as $\mathrm{Zn}$ deficient, resulting from fixation of $\mathrm{Zn}$ with other minerals, which may have caused a better response to the added $\mathrm{Zn}$ with the LC.

\subsection{Effect of Management Practices on N Uptake and Use Efficiency}

Low NUE in our study is in agreement with other past research. In intensive agricultural production systems, more than $50 \%$ and up to $75 \%$ of the $\mathrm{N}$ applied to the field is not used by the plant [48,49]. Low NUE in MT agrees with Yang et al. [50] who, in a 2-year experiment in China, found that NUE is comparatively lower under a no tillage field. By contrast, Liu et al. [10], in a two-year field study in China, observed no differences in NUE between no-tillage and conventional tillage systems. The variation in NUE may be due to the variations in $\mathrm{N}$ mineralization in two tillage systems, resulting in the $\mathrm{N}$ release and uptake by crops.

Similarly, N uptake was increased in R, while the NUE was equal in R and NR. Agegnehu et al. [51] found that the trend of plant $\mathrm{N}$ uptake increases in relation to organic amendments and $\mathrm{N}$ levels are similar to the increments in the plant growth, yield, and soil nutrient status. After conducting a 7-year experiment, Takahashi et al. [52] suggested that continuous application of rice straw contributes to the improvement of soil fertility and the promotion of growth and N uptake of paddy and upland crops. Conversely, Phongpan and Mosier [53], in a 1-year experiment in Thailand, observed no difference in $\mathrm{N}$ uptake between rice residue retention and no residue retention, which is in opposition to our results. The authors also found no differences in NUE between residue retention and no retention, which agrees with our findings.

The LC increased the NUE over the RD and BS by enhancing the N uptake in grain and straw, while the yield was also higher in LC. Higher N uptake in LC-treated soils might have happened due to accumulation of $\mathrm{N}$ and other nutrients in soils from the chronic bio-compost application in six consecutive seasons that improved soil biological and physic-chemical conditions, which favored $\mathrm{N}$ release from LC-treated soils at a faster rate. Tillage systems with application of different organic and inorganic $\mathrm{N}$ sources may enhance the mineralization rates of organic residues and release more nutrients, resulting in greater N uptake. Similar to our results, Hu et al. [45], from a 35-year study of organic alone or integrated organic and inorganic fertilization, concluded that $\mathrm{N}$ uptake in the manure combined with mineral fertilizer treatments were higher than that in manure alone or mineral fertilizer alone. They also found that use of manures alone, or with inorganic fertilizer, increases NUE in rice systems, which agrees with our results. However, comparing our short-term effects with their long-term reports, it can be suggested that continuation with ISFM will increase NUE in intensively managed rice ecosystems. Equally, Liu et al. [10] found that combined application of organic and inorganic fertilizers significantly increases NUE in rice-based cropping systems.

\subsection{Effect of Management Practices on Soil Aggregate MWD}

The MWD is an important physical indicator of soil aggregate stability [54], reflecting the proportion of macroaggregates to the total aggregates [55]. In our study, aggregate MWD was higher in MT than in CT, indicating that rice soil under CT reduces aggregate formation and enhances dispersion of larger aggregates. For rice cultivation, continuous puddling operations increase slaking of soil aggregates and cause their breakdown into microaggregates and primary soil particles $[4,15,56]$. Relatively improved soil aggregate formation in the MT agrees with the results of other studies [57,58]. Physical disturbance associated with CT results in a direct breakdown, slaking and an increased turnover of aggregates, especially macroaggregates [59] and fragments of roots and mycorrhizal hyphae, which are major binding agents for macroaggregate formation [60]. Frequent tillage deteriorates soil structure and weakens soil aggregates, causing them to be dispersed [24]. 
In contrast, the MT reduces soil physical disturbance as well as reduces SOM decomposition rates by reducing its exposure to $\mathrm{O}_{2}$ and sunlight. Moreover, the MT helps form macroaggregates by complexing microaggregates and primary soil particles with humified SOC compounds, fungal hyphae, and plant roots [61].

A significant impact of crop residue retention on soil aggregate properties might have been due to the increased SOC, TN, and microbial biomass that contribute to improved soil aggregate formation, which is in agreement with past research [62]. The C:N ratio of the residues determines their decomposition and subsequent utilization by microbes to influence soil aggregate properties [63,64]. The high C:N ratio of rice straw (C:N $=80)$ has lower mineralization rates, which can enhance soil aggregation due to its longer persistence in soil as a particulate organic matter. Residue quality (such as $\mathrm{C}: \mathrm{N}$ ) alters the rate of decomposition of the residue and, therefore, influences soil aggregation [65].

Improvements in aggregate MWD following additional organic amendments have already been reported [66]. Application of organic manures improves soil aggregation by increasing the organic matter content in soils, which functions as a binding agent for soil aggregate formation and reduces slaking of macroaggregates. Application of organic fertilizer often increases SOC content [67] and the proportion of macroaggregates [68]. Also, organic amendments may indirectly affect aggregate MWD by increasing above and belowground crop biomass and biological activity. Guo et al. [69] reported that soil aggregate MWD, which was strongly correlated with various fractions of SOC, significantly increased with manure application. Mikha et al. [70] pointed out that manure application promoted the formation of macroaggregates and increased aggregate MWD. Trichocompost is a fungi-bearing bio-compost that can enhance soil aggregate formation by accumulating soil particles with fungal hyphae, especially in MT with crop residues.

\subsection{Effect of Management Practices on Post-Harvest OC and TN Contents in Soils}

Numerous past authors have shown experimental evidence of higher SOC and $\mathrm{TN}[37,71]$ in MT than in CT. These findings are in line with our short- term study, indicating the potential of MT for enhancing SOC and TN. Conservation tillage is becoming an economical and ecologically viable option for conserving energy and providing favorable soil conditions for sustainable crop production, SOC sequestration, and efficient $\mathrm{N}$ fertilizer use [72]. Tian et al. [73] found $29 \%$ and $91 \%$ higher SOC in NT than in CT and RT, respectively. Adoption of some form of conservation tillage is generally beneficial for increasing SOC levels and sequestering $C$ in the topsoil [34]. In the case of CT, the organic source may be easily subjective to oxidization, and microbes quickly consume the mineralized $\mathrm{N}$ for their structure formation, which may be the reason behind the decrease of TN in $\mathrm{CT}$ in post-harvest soils. To the contrary, nitrification can be inhibited in MT under field conditions because of accumulation of organic matter and nutrients, such as $\mathrm{N}$, at or near the soil surface that may restrict $\mathrm{N}$ mineralization. In addition, lack of soil disturbance due to factors such as no-tillage systems helps to minimize organic matter loss and increase SOC and N stocks over the years [74]. It occurs because under a no tillage system, crop residue is made available to soil microorganisms at a slower rate for a longer duration and the soil is in a less oxidative condition [75]. No differences in the post-harvest soil C and $\mathrm{N}$ contents in soil after two consecutive years of residue management agree with other previous authors [76]. This may be attributable to faster mineralization of rice residues, or a mixture of rice residues with maize or wheat [76]. Datta et al. [76] also found higher decomposition rates of rice residue when placed on the soil surface rather than incorporated into the soils. In our study, the effect was similar in both tillage systems because the climatic condition in our subtropical environment might have minimized the effect of partial or full incorporation into the soils. However, continuation of residue management in rice-based systems enhances $C$ sequestration after 4 or 6 years [15], and after 12 years [52]. In our study, the ISFM with LC and BS were like the RD for SOC content. The combined application of manures with inorganic fertilizers on SOC yielded similar results in our study to those found by other authors [77]. However, the ISFM can enhance SOC content if 
it is continued for several years. Zhao et al. [78], from a 4-year experiment, suggested that supplementation with compost strengthened the process of mutual promotion between carbon cycle enzymes and macroaggregates, which would eventually be beneficial to SOC sequestration. Bilkis et al. [17] reported that integrated application of Trichocompost in a rice field increases SOC and $\mathrm{N}$ after a 2-year cycle. Trichocompost is a rapid decomposer of $\mathrm{SOM}$, which can rapidly release $\mathrm{C}$ and $\mathrm{N}$ in soils and accumulate within soil aggregates.

\subsection{Effect of Management Practices on Post-Harvest Soil-Available P and S Contents}

No-till reduces losses of phosphorus in runoff and the loss of nitrate through leaching, allowing accumulation in soils [79]. Equally, Asenso et al. [80] found higher available P, S, and exchangeable K content in soils under NT and MT than the soils under deep tillage, probably due to high SOC level and surface application of mineral fertilizers. These results are in agreement with the findings of our research. From a 4-year tillage experiment, Alam et al. [34] found that MT and zero tillage significantly increased soil's available S, which is in line with the current research. Available S content in our soils were comparatively low, which can be attributed to soil conditions while sampling after harvesting of Aman rice when the soil was comparatively wet, which can cause soil available $S$ to be reduced. Bilkis et al. [17] from a study of 2 consecutive years of the integrated application of Trichocompost, vermicompost, and bio-slurry found that the integrated application of composts and inorganic fertilizers improves soil $\mathrm{P}$ and $\mathrm{S}$ content where Trichocompost showed the best performance. This is attributable to higher S-containing organic compounds in LC and BS, or mineralization of the $S$ pools, which are more mobile [81] and result in a higher amount of residual $S$ than P. In addition, P can be fixed with various soil minerals [82] and organic fractions (organo-P chelation), which minimized the effect of ISFM on the residual P content in soils. Along with the physical and chemical properties, soil microbial composition and activities should be evaluated to investigate the effects of composts and other organic materials on soil health. As the current research had no scope to present microbial data, we recommend future research on microbial dynamics that justifies composts effects on soil health [83] for sustainable food security and soil fertility.

\section{Conclusions}

Short-term evaluation of conservation agriculture with ISFM indicates that it is likely to be a good practice for the sustenance of soil fertility. Minimum soil disturbance in minimum tillage with crop residue improved soil aggregate properties and stored more $\mathrm{C}, \mathrm{N}, \mathrm{P}$, and S. Conventional tillage had higher rice equivalent yield, grain $\mathrm{N}$ contents, and uptake showing higher potential to supply more available $\mathrm{N}$ through mineralization. Correspondingly, the $\mathrm{N}$-use efficiency was also higher in conventional tillage because of higher $\mathrm{N}$ uptake and accumulation in grain. Trichocompost and bio-slurry have increased $\mathrm{N}$ uptake in rice when compared with the recommended fertilizer. The Trichoderma biocompost indicated higher potential for increased crop production, as well as to improve soil health; there was no threat to accumulate heavy metals in soils. The findings are based on short-term results, but it is important to evaluate medium and long-term effects on soil structural and elemental quality and crop yields.

Supplementary Materials: The following are available online at https://www.mdpi.com/article/10 .3390 /agronomy11112101/s1, Supplementary Materials 1. Layout of the experimental plots.

Author Contributions: Conceptualization, M.M.R.J., S.I., A.K.M.A.K. and M.B.M.; methodology, M.M.R.J. and S.I.; software, S.I., T.T.N. and S.U.; validation, M.M.R.J., S.I., M.B.M. and A.K.M.A.K.; formal analysis, M.M.R.J., S.I., T.T.N. and S.U.; investigation, M.M.R.J., S.I., A.K.M.A.K. and M.B.M.; resources, M.M.R.J. and S.I.; data curation, M.M.R.J., S.I. and S.U.; writing—original draft preparation, M.M.R.J., S.I. and T.T.N.; writing-review and editing, M.M.R.J., S.I., T.T.N., S.U., A.K.M.A.K., M.B.M. and R.I.; visualization, M.M.R.J., S.I., S.U. and R.I.; supervision, M.M.R.J., A.K.M.A.K. and M.B.M.; project administration, M.M.R.J.; funding acquisition, M.M.R.J., M.B.M. and A.K.M.A.K. All authors have read and agreed to the published version of the manuscript. 
Funding: The research was funded by the Bangladesh Agricultural University Research Systems in association with University Grants Commission Bangladesh (grant \# 2017/261/BAU).

Institutional Review Board Statement: Not applicable.

Informed Consent Statement: Not applicable.

Data Availability Statement: The data that support this study will be shared upon reasonable request to the corresponding author.

Acknowledgments: Thanks to Abdulla Al Mamun in the Department of Soil Science for his cooperation during field and lab work. We would like to thank Bradford Sherman at The Ohio State University for his contribution to review and edit the manuscript.

Conflicts of Interest: The authors declare that they have no conflict of interest.

\section{References}

1. Delgado, J.A.; Groffman, P.M.; Nearing, M.A.; Goddard, T.; Reicosky, D.; Lal, R.; Kitchen, N.R.; Rice, C.W.; Towery, D.; Salon, P. Conservation practices to mitigate and adapt to climate change. J. Soil Water Conserv. 2011, 66, 118-129. [CrossRef]

2. Hasan, M.N.; Hossain, M.S.; Bari, M.A.; Islam, M.R. Agricultural Land Availability in Bangladesh; SRDI: Dhaka, Bangladesh, 2013; p. 42.

3. Lal, R. Tillage effects on soil degradation, soil resilience, soil quality, and sustainability. Soil Till. Res. 1993, 27, 1-8. [CrossRef]

4. Jahangir, M.M.R.; Jahiruddin, M.; Akter, H.; Pervin, R.; Islam, K.R. Cropping diversity with rice influences soil aggregate formation and nutrient storage under different tillage systems. J. Plant. Nutr. Soil Sci. 2021, 184, 150-161. [CrossRef]

5. Chauhan, B.S.; Mahajan, G.; Sardana, V.; Timsina, J.; Jat, M.L. Productivity and sustainability of the rice-wheat cropping system in the Indo-Gangetic Plains of the Indian subcontinent: Problems, opportunities, and strategies. Advan. Agron. 2012, 117, 315-369.

6. Lal, R. Sequestering carbon and increasing productivity by conservation agriculture. J. Soil Water Conserv. 2015, 70, 56-62. [CrossRef]

7. Martínez, J.M.; Galantini, J.A.; Duval, M.E.; López, F.M. Soil quality assessment based on soil organic matter pools under long-term tillage systems and following tillage conversion in a semi humid region. Soil Use Manag. 2020, 36, 400-409. [CrossRef]

8. Huang, M.; Zhuo, X.; Cao, F.; Xia, B.; Zou, Y. No-tillage effect on rice yield in China: A meta-analysis. Field Crops. Res. 2015, 183, 126-137. [CrossRef]

9. Awale, R.; Emeson, M.A.; Machado, S. Soil organic carbon pools as early indicators for soil organic matter stock changes under different tillage practices in inland Pacific Northwest. Front. Ecol. Evol. 2017, 5, 96. [CrossRef]

10. Liu, T.; Huang, J.; Chai, K.; Cao, C.; Li, C. Effects of $\mathrm{N}$ fertilizer sources and tillage practices on $\mathrm{NH}_{3}$ volatilization, grain yield, and $\mathrm{N}$ use efficiency of rice fields in central China. Front. Plant Sci. 2018, 9, 385. [CrossRef] [PubMed]

11. IPCC. Climate Change: Synthesis Report; Intergovernmental Panel on Climate Change: Geneva, Switzerland, 2014.

12. Dey, A.; Dwivedi, B.S.; Bhattacharyya, R.; Datta, S.P.; Meena, M.C.; Jat, R.K.; Gupta, R.K.; Jat, M.L.; Singh, V.K.; Das, D.; et al. Effect of conservation agriculture on soil organic and inorganic carbon sequestration, and their lability: A study from a rice-wheat cropping system on a calcareous soil of eastern Indo-Gangetic Plains. Soil Use Manag. 2018, 36, 429-438. [CrossRef]

13. Young, M.D.; Ros, G.H.; de Vries, W. A decision support framework assessing management impacts on crop yield, soil carbon changes and nitrogen losses to the environment. Eur. J. Soil Sci. 2021, 72, 1590-1606. [CrossRef]

14. Memon, M.S.; Guo, J.; Tagar, A.A.; Perveen, N.; Ji, C.; Memon, S.A.; Memon, N. The effects of tillage and straw incorporation on soil organic carbon status, rice crop productivity, and sustainability in the rice-wheat cropping system of Eastern China. Sustainability 2018, 10, 961. [CrossRef]

15. Jat, H.S.; Datta, A.; Choudhary, M.; Yadav, A.K.; Choudhary, V.; Sharma, P.C.; Gathala, M.K.; Jat, M.L.; McDonald, A. Effects of tillage, crop establishment and diversification on soil organic carbon, aggregation, aggregate associated carbon and productivity in cereal systems of semi-arid Northwest India. Soil Till. Res. 2019, 190, 128-138. [CrossRef] [PubMed]

16. Roobroeck, D.; Van Asten, P.J.A.; Jama, B.; Harawa, R.; Vanlauwe, B. Integrated Soil Fertility Management: Contributions of framework and practices to Climate-Smart Agriculture. In PRACTICE BRIEF Climate-Smart Agriculture; CGIAR Research Program on Climate Change, Agriculture and Food Security (CCAFS): Copenhagen, Denmark, 2015; Available online: https: / /hdl.handle.net/10568/69018 (accessed on 15 December 2020).

17. Bilkis, S.; Islam, M.R.; Jahiruddin, M.; Rahman, M.M. Integrated use of manure and fertilizers increases rice yield, nutrient uptake and soil fertility in the Boro-fallow-T. Aman rice cropping pattern. SAARC J. Agric. 2017, 15, 147-161. [CrossRef]

18. Matin, M.A.; Islam, M.N.; Muhammad, N.; Islam, M.R. Impact of Trichoderma enhanced composting technology on farmers' livelihoods in Bangladesh. Int. J. Plant. Soil Sci. 2018, 25, 1-14. [CrossRef]

19. Singh, D.P.; Prabha, R.; Renu, S.; Sahu, P.K.; Singh, V. Agrowaste bioconversion and microbial fortification have prospects for soil health, crop productivity, and eco-enterprising. Int. J. Recycl. Org. Waste Agric. 2019, 8, 457-472. [CrossRef] 
20. Fels, L.E.; Hayany, B.E.; Aguelmous, A.; Boutafda, A.; Zegzouti, Y.; Ghizlen, E.; Kouisni, L.; Hafidi, M. The Use of Microorganisms for the Biodegradation of Sewage Sludge and the Production of Bio-compost for Sustainable Agriculture. In Biofertilizers for Sustainable Agriculture and Environment; Giri, B., Prasad, R., Wu, Q.S., Varma, A., Eds.; Springer: Cham, Switzerland; New York, NY, USA, 2019; pp. 301-316.

21. Islam, M.R.; Jahan, R.; Uddin, S.; Harine, I.J.; Hoque, M.A.; Hassan, S.; Hassan, M.M.; Hossain, M.A. Lime and Organic Manure Amendment Enhances Crop Productivity of Wheat-Mungbean-T. Aman Cropping Pattern in Acidic Piedmont Soils. Agriculture 2021, 11, 1595. [CrossRef]

22. De Leenheer, L.; De Boodt, M. Determination of aggregate stability by change in mean weight diameter. Meded. Lundbouwhogeschool Gent 1967, 24, 290-300.

23. Van Bavel, C.H.M. Mean Weight-Diameter of Soil Aggregates as a Statistical Index of Aggregation. Soil Sci. Soc. Am. J. 1950, 14, 20-23. [CrossRef]

24. Zheng, H.; Liu, W.; Zheng, J.; Luo, Y.; Li, R.; Wang, H. Effect of long-term tillage on soil aggregates and aggregate-associated carbon in black soil of Northeast China. PLoS ONE 2018, 13, e0199523. [CrossRef]

25. Walkley, A. A critical examination of a rapid method for determining organic carbon in soils-effect of variations in digestion conditions and of inorganic soil constituents. Soil Sci. 1947, 63, 251-264. [CrossRef]

26. Fawcett, J.K. The semi-micro Kjeldahl method for the determination of nitrogen. J. Med. Lab. Technol. 1954, 12, 1-22.

27. Olsen, S.R.; Cole, C.V.; Watanabe, F.S.; Dean, L.A. Estimation of Available Phosphorus in Soils by Extraction with Sodium Bicarbonate; United States Department of Agriculture, Circular 939; United States Government Printing Office: Washington, DC, USA, 1954.

28. Williams, C.H.; Steinbergs, A. Soil sulfur fractions as chemical indices of available sulfur in some Australian soils. Aus. J. Agric. Res. 1959, 10, 340-352. [CrossRef]

29. Weih, M.; Hamnér, K.; Pourazari, P. Analyzing plant nutrient uptake and utilization efficiencies: Comparison between crops and approaches. Plant. Soil 2018, 430, 7-21. [CrossRef]

30. EUNEP. Nitrogen Use Efficiency (NUE)—An Indicator for the Utilization of Nitrogen in Agriculture and Food Systems; Wageningen University: Wageningen, The Netherlands, 2015.

31. Masunga, R.H.; Uzokwe, V.N.; Mlay, P.D.; Odeh, I.; Singh, A.; Buchan, D.; de Neve, S. Nitrogen mineralization dynamics of different valuable organic amendments commonly used in agriculture. Appl. Soil Ecol. 2016, 101, 185-193. [CrossRef]

32. Zeb, H.; Hussain, A.; Naveed, M.; Ditta, A.; Ahmad, S.; Jamshaid, M.U.; Ahmad, H.T.; Hussain, M.B.; Aziz, R.; Haider, M.S. Compost enriched with $\mathrm{ZnO}$ and $\mathrm{Zn}$-solubilizing bacteria improves yield and $\mathrm{Zn}$-fortification in flooded rice. Ital. J. Agron. 2018, 13, 310-316. [CrossRef]

33. Rahman, M.S.; Haque, M.A.; Salam, M.A. Effect of different tillage practices on growth, yield and yield contributing characters of transplanted Aman rice (BRRI Dhan-33). Agron. J. 2004, 3, 103-110.

34. Alam, M.K.; Islam, M.M.; Salahin, N.; Hasanuzzaman, M. Effect of tillage practices on soil properties and crop productivity in wheat-mungbean-rice cropping system under subtropical climatic conditions. Sci. World J. 2014, 437283. [CrossRef]

35. Arvidsson, J.; Håkansson, I. Does soil compaction persist after ploughing—Results from 21 long-term field experiments? Soil Till. Res. 1996, 39, 175-198. [CrossRef]

36. De Cárcer, P.S.; Sinaj, S.; Santonja, M.; Fossati, D.; Jeangros, B. Long-term effects of crop succession, soil tillage and climate on wheat yield and soil properties. Soil Till. Res. 2019, 190, 209-2019. [CrossRef]

37. Nandan, R.; Singh, V.; Singh, S.S.; Kumar, V.; Hazra, K.K.; Nath, C.P.; Pooni, S.; Malik, R.K.; Bhattacharyya, R.; McDonald, A. Impact of conservation tillage in rice-based cropping systems on soil aggregation, carbon pools and nutrients. Geoderma 2019, 340, 104-114. [CrossRef]

38. Yadav, G.S.; Datta, R.; Pathan, S.I.; Lal, R.; Meena, R.S.; Babu, S.; Das, A.; Bhowmik, S.N.; Datta, M.; Saha, P.; et al. Effects of conservation tillage and nutrient management practices on soil fertility and productivity of rice in North Eastern Region of India. Sustainability 2017, 9, 1816. [CrossRef]

39. Jahangir, M.M.R.; Jahan, I.; Mumu, N.J. Management of soil resources for sustainable development under a changing climate. J. Environ. Sci Nat. Resour 2018, 11, 159-170. [CrossRef]

40. Hossain, I.; Sarker, M.J.U.; Hoque, M.A. Status of conservation agriculture-based tillage technology for crop production in Bangladesh. Bangladesh. J. Agric Res. 2015, 40, 235-248. [CrossRef]

41. Lu, X. A meta-analysis of the effects of crop residue returns on crop yields and water use efficiency. PLoS ONE 2020, 15, e0231740. [CrossRef] [PubMed]

42. Srivastava, P.K.; Gupta, M.; Upadhyay, R.K.; Sharma, S.; Singh, N.; Tewari, S.K.; Singh, B. Effects of combined application of vermin-compost and mineral fertilizer on the growth of Allium cepa and soil fertility. J. Soil Sci. Plant. Nutr. 2012, 175, 101-107. [CrossRef]

43. Uddin, U.; Nitu, T.T.; Milu, U.M.; Nasreen, S.S.; Hosenuzzaman, M.; Haque, M.E.; Hossain, B.; Jahiruddin, M.; Bell, R.W.; Müller, C.; et al. Ammonia fluxes and emission factors under an intensively managed wetland rice ecosystem. Environ. Sci. Process. Impacts 2021, 23, 132-143. [CrossRef] [PubMed]

44. Haque, M.A.; Jahiruddin, M.; Islam, M.S.; Rahman, M.M.; Saleque, M.A. Effect of bioslurry on the yield of wheat and rice in the wheat-rice cropping system. Agric. Res. 2018, 7, 432-442. [CrossRef]

45. Hu, C.; Xia, X.G.; Chen, Y.F.; Qiao, Y.; Liu, D.H.; Fan, J.; Li, S.L. Yield, nitrogen use efficiency and balance response to thirty-five years of fertilization in paddy rice-upland wheat cropping system. Plant. Soil Environ. 2019, 65, 55-62. 
46. Abbasi, M.K.; Hina, M.; Khalique, A.; Khan, S.R. Mineralization of Three Organic Manures Used as Nitrogen Source in a Soil Incubated under Laboratory Conditions. Commun. Soil Sci. Plant. Anal. 2007, 38, 1691-1711. [CrossRef]

47. Celar, F.; Valic, N. Effects of Trichoderma spp. and Glicladium roseum culture filtrates on seed germination of vegetables and maize. J. Plant. Dis. Protect. 2005, 112, 343-350.

48. Asghari, H.R.; Cavagnaro, T.R. Arbuscular mycorrhizae as enhance plant interception of leached nutrients. Funct. Plant. Biol. 2011, 38, 219-226. [CrossRef] [PubMed]

49. San Francisco, S.; Urrutia, O.; Martin, V.; Peristeropoulos, A.; Garcia-Mina, J.M. Efficiency of urease and nitrification inhibitors in reducing ammonia volatilization from diverse nitrogen fertilizers applied to different soil types and wheat straw mulching. J. Soc. Food Agric. 2011, 91, 1569-1575. [CrossRef]

50. Yang, C.; Xu, S.; Liu, L.; Huang, M.; Zheng, T.; Wei, S.; Zhang, Y.; Deng, G.; Jiang, L. Nitrogen uptake and utilization by no-tillage rice under different soil moisture conditions-A model study under simulated soil conditions. Plant. Product Sci. 2015, 18, 118-127. [CrossRef]

51. Agegnehu, G.; Nelson, P.N.; Bird, M.I. Crop yield, plant nutrient uptake and soil physicochemical properties under organic soil amendments and nitrogen fertilization on nitisols. Soil Till. Res. 2016, 160, 1-13. [CrossRef]

52. Takahashi, S.; Uenosono, S.; Ono, S. Short and long-term effects of rice straw application on nitrogen uptake by crops and nitrogen mineralization under flooded and upland conditions. Plant. Soil 2003, 251, 291-301. [CrossRef]

53. Phongpan, S.; Mosier, A. Impact of organic residue management on nitrogen use efficiency in an annual rice cropping sequence of lowland Central Thailand. Nutr. Cycl. Agroecosyst. 2003, 66, 233-240. [CrossRef]

54. Li, L.Q.; Zhang, X.H.; Zhang, P.J.; Zheng, J.F.; Pan, G.X. Variation of organic carbon and nitrogen in aggregate size fractions of a paddy soil under fertilization practices from Tai Lake Region, China. J. Sci. Food Agric. 2007, 87, 1052-1058. [CrossRef]

55. Kihara, J.A.; Bationo, D.N.; Mugendi, C.; Martius, C.; Vlek, P.L.G. Conservation tillage, local organic resources and nitrogen fertilizer combinations affect maize productivity, soil structure and nutrient balances in semi-arid Kenya. Nutr. Cycl. Agroecosyst. 2011, 90, 213-225. [CrossRef]

56. Amézketa, E.; Aragüés, R.; Carranza, R.; Urgel, B. Macro-and micro-aggregate stability of soils determined by a combination of wet-sieving and laser-ray diffraction. Span. J. Agric. Res. 2003, 1, 83-94. [CrossRef]

57. Nyamadzawo, G.; Nyamangara, J.; Nyamugafata, P.; Muzulu, A. Soil microbial biomass and mineralization of aggregate protected carbon in fallow-maize systems under conventional and no-tillage in Central Zimbabwe. Soil Till. Res. 2009, 102, 151-157. [CrossRef]

58. Fuentes, M.; Hidalgo, C.; Etchevers, J.; De León, F.; Guerrero, A.; Dendooven, L.; Verhulst, N.; Govaerts, B. Conservation agriculture increased organic carbon in the topsoil macro-aggregates and reduced soil $\mathrm{CO}_{2}$ emissions. Plant. Soil 2012, 355, 183-197. [CrossRef]

59. Six, J.; Elliott, E.T.; Paustian, K. Soil macroaggregate turnover and microaggregate formation: A mechanism for C sequestration under no-tillage agriculture. Soil Biol. Biochem. 2000, 2, 2099-2103. [CrossRef]

60. Bronick, C.J.; Lal, L. Soil structure and management: A review. Geoderma 2005, 124, 3-22. [CrossRef]

61. Blanco-Moure, N.; Moret-Fernández, D.; López, M.V. Dynamics of aggregate destabilization by water in soils under long-term conservation tillage in semiarid Spain. Catena 2012, 99, 34-41. [CrossRef]

62. Chu, J.; Zhang, T.; Chang, W.; Zhang, D.; Zulfiqar, S.; Fu, A. Impacts of cropping systems on aggregates associated organic carbon and nitrogen in a semiarid highland agroecosystem. PLoS ONE 2016, 11, e0165018. [CrossRef]

63. Tivet, F.; de Moraes Sá, J.C.; Lal, R.; Briedis, C.; Borszowskei, P.R.; dos Santos, J.B.; Farias, A.; Eurich, G.; Hartman, D.D.C.; Nadolny, J.M.; et al. Aggregate $C$ depletion by plowing and its restoration by diverse biomass-C inputs under no-till in sub-tropical and tropical regions of Brazil. Soil Till. Res. 2013, 126, 203-218. [CrossRef]

64. Zhou, M.; Liu, C.; Wang, J.; Meng, Q.; Yuan, Y.; Ma, X.; Liu, X.; Zhu, Y.; Ding, G.; Zhang, J.; et al. Soil aggregate stability and storage of soil organic carbon respond to cropping systems on Black Soils of Northeast China. Sci. Rep. 2020, 10, 265. [CrossRef] [PubMed]

65. Sainju, U.M.; Whitehead, W.F.; Singh, B.P. Cover crops and nitrogen fertilization effects on soil aggregation and carbon and nitrogen pools. Can. J. Soil Sci. 2003, 83, 155-165. [CrossRef]

66. Caravaca, F.; Lax, A.; Albaladejo, J. Soil aggregate stability and organic matter in clay and fine silt fractions in urban refuseamended semiarid soils. Soil Sci. Soc. Am. J. 2001, 65, 1235-1238. [CrossRef]

67. Yu, H.Y.; Ding, W.X.; Luo, J.F.; Geng, R.L.; Cai, Z.C. Long-term application of organic manure and mineral fertilizers on aggregation and aggregate-associated carbon in a sandy loam soil. Soil Till. Res. 2012, 124, 170-177. [CrossRef]

68. Huang, S.; Peng, X.X.; Huang, Q.R.; Zhang, W.J. Soil aggregation and organic carbon fractions affected by long-term fertilization in a red soil of subtropical China. Geoderma 2010, 154, 364-369. [CrossRef]

69. Guo, Z.; Zhang, L.; Yang, W.; Hua, L.; Cai, C. Aggregate stability under long-term fertilization practices: The case of eroded Ultisols of South-Central China. Sustainability 2019, 11, 1169. [CrossRef]

70. Mikha, M.M.; Hergert, G.W.; Benjamin, J.G.; Jabro, J.D.; Nielsen, R.A. Long-term manure impacts on soil aggregates and aggregate-associated carbon and nitrogen. Soil Sci. Soc. Am. J. 2015, 79, 626-636. [CrossRef]

71. Khorami, S.S.; Kazemeini, S.A.; Afzalinia, A.; Gathala, M.K. Changes in soil properties and productivity under different tillage practices and wheat genotypes: A Short-term study in Iran. Sustainability 2018, 10, 3273. [CrossRef] 
72. Mazzoncini, M.; Sapkota, T.B.; Bàrberi, P.; Antichi, D.; Risalati, R. Long-term effect of tillage, nitrogen fertilization and cover crops on soil organic carbon and total nitrogen content. Soil Till. Res. 2011, 114, 165-174. [CrossRef]

73. Tian, Q.; He, H.; Cheng, W.; Bai, Z.; Wang, Y.; Zhang, X. Factors controlling soil organic carbon stability along a temperate forest altitudinal gradient. Sci. Rep. 2016, 6, 18783. [CrossRef]

74. Diekow, J.; Mielniczuk, J.; Knicker, H.; Bayer, C.; Dick, D.P.; Kögel-Knabner, I. Soil C and N stocks as affected by cropping systems and $\mathrm{N}$ fertilization in the southern Brazil Acrisol managed under no-tillage for 17 years. Soil Till. Res. 2005, 81, 87-95. [CrossRef]

75. Kheyrodin, H.; Ghazvininan, K.; Taherian, M. Tillage and manure effect on soil microbial biomass and respiration, and on enzyme activities. Afr. J. Biotechnol. 2012, 11, 14652-14659.

76. Datta, A.; Jat, H.S.; Yadav, A.K.; Choudhary, M.; Sharma, P.C.; Rai, M.; Kumar, L.; Majumder, S.P.; Choudhary, V.; Jat, M.L. Carbon mineralization in soil as influenced by crop residue type and placement in an Alfisols of Northwest India. Carbon Manag. 2019, 10,37-50. [CrossRef]

77. Ren, T.; Wang, J.; Chen, Q.; Zhang, F.; Lu, S. The effects of manure and nitrogen fertilizer applications on soil organic carbon and nitrogen in a high-input cropping system. PLoS ONE 2014, 9, e97732. [CrossRef]

78. Zhao, Z.; Zhang, C.; Li, F.; Gao, S.; Zhang, J. Effect of compost and inorganic fertilizer on organic carbon and activities of carbon cycle enzymes in aggregates of an intensively cultivated Vertisol. PLoS ONE 2020, 15, e0229644. [CrossRef] [PubMed]

79. Soane, B.; Bruce, C.; Ball, B.C.; Arvidsson, J.; Basch, G.; Moreno, F.; Roger-Estade, J. No-till in northern, western and south western Europe: A review of problems and opportunities for crop production and the environment. Soil Till. Res. 2012, 118, 66-87. [CrossRef]

80. Asenso, E.; Li, J.; Hu, L.; Issaka, F.; Tian, K.; Zhang, L.; Chen, H. Tillage effects on soil biochemical properties and maize grown in latosolic red soil of southern China. Appl. Environ. Soil Sci. 2018, 2018, 8426736.

81. Zhou, W.; Li, S.T.; Wang, H.; He, P.; Lin, B. Mineralization of organic sulfur and its importance as a reservoir of plant-available sulfur in upland soils of north China. Biol. Fert. Soils 1999, 30, 245-250. [CrossRef]

82. Samuel, A.L.; Ebenezer, A.O. Mineralization rates of soil forms of nitrogen, phosphorus, and potassium as affected by organomineral fertilizer in sandy loam. Adv. Agric. 2014, 2014, 1-5. [CrossRef]

83. Durrer, A.; Gumiere, T.; Rumenos Guidetti Zagatto, M.; Petry Feiler, H.; Miranda Silva, A.M.; Henriques Longaresi, R.; Homma, S.K.; Cardoso, E.J.B.N. Organic farming practices change the soil bacteria community, improving soil quality and maize crop yields. PeerJ 2021, 9, e11985. [CrossRef] [PubMed] 